\title{
Dating of late Archaean crustal mobilisation north of Qugssuk, Godthåbsfjord, southern West Greenland
}

\author{
A. A. Garde, O. Larsen and A. P. Nutman
}

\begin{abstract}
The Taserssuaq tonalite, which is slightly younger than or coeval with the common grey gneisses north of Godthåbsfjord, has yielded a zircon U-Pb age of $2982 \pm 7 \mathrm{Ma}$, and an apparent $\mathrm{Rb}-\mathrm{Sr}$ whole-rock age of $2882 \pm 36 \mathrm{Ma}\left(\mathrm{MSWD}=1.57\right.$, initial ${ }^{87} \mathrm{Sr} /{ }^{86} \mathrm{Sr}=$ $0.7017)$. The minerals were isotopically equilibrated at $2500 \mathrm{Ma}$, and finally biotite was reset at $1700 \mathrm{Ma}$. The Qugssuk granite, an adjacent granitic mobilisate, has yielded a $\mathrm{Rb}$-Sr age of $2969 \pm 32 \mathrm{Ma}\left(\mathrm{MSWD}=1.09\right.$, initial $\left.{ }^{87} \mathrm{Sr}{ }^{86} \mathrm{Sr}=0.7020\right)$. The intrusion of the Taserssuaq tonalite is probably dated by its zircon age, which broadly correlates it with the Nûk gneisses. Field relations and microtextures strongly suggest that the Qugssuk granite is younger than the Taserssuaq tonalite and post-dates granulite facies metamorphism in the area, and its formation may be related to the extensive retrogression of the Taserssuaq tonalite. Isotopic data may support this interpretation in spite of the apparent inconsistencies in the age values.
\end{abstract}

\section{Introduction}

This paper deals with late stages in the Archaean evolution of continental crust north of Qugssuk and around Taserssuaq, north of Godthåbsfjord, and an attempt to date these events by U-Pb zircon and $\mathrm{Rb}-\mathrm{Sr}$ whole-rock age determinations. The area is situated at about $65^{\circ} \mathrm{N}, 51^{\circ} \mathrm{W}$, and spans the boundary between the $1: 100000$ scale Fiskefjord and Isukasia map sheets. Geological mapping for the Isukasia sheet was completed in 1982, while field work for the former sheet is still in progress.

In the Godthåbsfjord area, just to the south, it has been possible to document Archaean crustal evolution from the deposition of the earliest Archaean supracrustal rocks (c. $3800 \mathrm{Ma}$ old) at Isukasia through the Amîtsoq gneisses, Malene supracrustals and Nûk gneisses to reworking of the older gneisses into the Qôrqut granite complex at the close of the Archaean. Here well preserved primary field relations have been described, even between such closely related rocks as successive batches of similar Nûk tonalites (e.g. Bridgwater et al., 1976, fig. 55). This favourable state of preservation is due to the absence of late Archaean granulite facies metamorphism.

By contrast, both north and south of the Godthăbsfjord region there is evidence of widespread late Archaean granulite facies metamorphism and subsequent partial retrogression, which has obscured and in some cases obliterated structures on outcrop scale and may also have upset the isotope systems in the affected rocks: while a detailed radiometric age chronology exists for the Godthåbsfjord region itself, late Archaean Rb-Sr isochron ages from the Fiskenæsset region further south often cannot be interpreted as dating specific geological events (Kalsbeek \& Pidgeon, 1980). On the north-western side of Godthåbsfjord only Pb-Pb age determinations from the outer coast of Nordlandet have been published (Black et al., 1973; Taylor et al., 1980), and these ages have been interpretated as dating granulite facies 
metamorphism closely following original crust formation. Field observations on the rocks discussed in the present paper have been published by Garde et al. (1983) and Garde (1984).

\section{Grey gneisses}

The area north of Qugssuk (fig. 1) consists mainly of grey gneisses which have intruded supracrustal rocks (predominantly amphibolite or pyribolite). Both gneisses and supracrustal rocks were subsequently folded into kilometre-scale isoclinal folds which now have upright axial surfaces and south plunging fold axes. The supracrustal rocks form steeply dipping to vertical bands and trains of inclusions in the gneisses. The grey gneisses are sodium-rich tonalitic to trondhjemitic biotite-amphibole-bearing rocks, generally medium grained and nebulitic or homogeneous. They sometimes have a patchy or streaky texture of ferromagnesian minerals clustered into centimetre-sized patches or drawn out into indistinct bands. Locally the grey gneisses gradually change into areas of darker, brown-grey, granoblastic orthopyroxene-bearing granulite facies rocks in a pattern discordant to large-scale structures and local trends of foliation.

In thin sections of rocks from transitional areas corroded orthopyroxene cores are partially replaced by biotite and amphibole, and in the common grey gneisses retrograde disequilibrium is shown by small clusters of radiating biotite crystals overgrowing ilmenite, poikiloblastic intergrowths between actinolitic amphibole and quartz, and locally new growth of sphene and/or epidote. Both field relations and petrographic observations thus indicate that these facies transitions are retrograde and that retrogression from granulite facies (but not necessarily the granulite facies event itself) took place under more or less static conditions after the main phase of deformation, and that a new equilibrium was never attained. The retrogression did not affect the mafic supracrustal rocks as severely as the gneisses. Equilibrium textures between hornblende, biotite, orthopyroxene \pm clinopyroxene and plagioclase are common in the mafic supracrustals in areas predominantly underlain by grey retrogressed tonalitic gneisses, as well as in areas dominated by remobilised granitic rocks (see below). It is emphasized that the widespread granulite facies parageneses in the supracrustals support the contention that the grey gneisses folded together with the supracrustals are former granulite facies rocks.

\section{Taserssuaq tonalite}

The Taserssuaq tonalite extends northwards past the lake Taserssuaq from the area between Qugssuk and Ilulialik in Godthåbsfjord and has an outcrop area of more than 1500 $\mathrm{km}^{2}$. It was briefly described by Garde et al. (1983). They concluded that its field relations to the grey gneisses on its western and northern sides are ambiguous and that the Taserssuaq pluton north of $65^{\circ} \mathrm{N}$ is generally more mafic and basic than formerly believed (Allaart et al., 1977). South of $65^{\circ} \mathrm{N}$ it also comprises rocks of granodioritic composition, but the two varieties can hardly be distinguished in the field, and no clear mutual contacts have been observed. In the area west of Taserssuaq it has not been possible to establish field criteria to delineate the western boundary to the grey gneisses, although a few kilometres west of lake Taserssuaq the tonalite does contain recognisable mega-inclusions of (more) foliated grey gneisses. Representative thin sections from within the central and western parts of the Taserssuaq tonalite all contain large proportions of hydrous mafic minerals with disequilibrium 
textures formed during wet, retrogressive, intermediate to low amphibolite facies metamorphic conditions. These microtextures much resemble those from the retrogressed grey gneisses, except that there is a higher proportion of mafic phases in most parts of the Taserssuaq tonalite. The retrogression seems to have proceeded further in the Taserssuaq tonalite with much growth of new epidote and sphene. Green chlorite often partially replaces biotite and amphibole. Granulite facies assemblages have only been reported from a small area east of Taserssuaq (Allaart, 1982). The former extent of the granulite facies is unknown, but it may have been widespread.

\section{Igánánguit pink gneiss and Qugssuk granite}

Two mappable units of leucocratic granitic rocks occur west of Taserssuaq and north of Qugssuk and are named the Igánánguit pink gneiss and Qugssuk granite, respectively. Both of them post-date the generally north-south trending isoclinally folded structures of grey gneiss and supracrustal rocks, but doming during their intrusion has modified local structures in the country rocks. The Igánánguit pink gneiss, named after a peninsula in northeastern Taserssuaq, is a pinkish grey fairly fine-grained granitic gneiss, with fine-grained biotite flakes evenly scattered or sometimes forming thin dark seams. It is bounded to the south and west by a prominent amphibolite marker, which forms a $6 \mathrm{~km}$ wide antiform with a moderately south-plunging axis. Amphibolite and associated grey gneiss markers and trains of amphibolite inclusions in the pink gneiss inside the large antiform structure form smaller north-facing closures with shallow northerly plunges, which are found a few kilometres to the north of the south-facing antiform. Together the amphibolite markers outline a composite domal structure consisting of one large south-plunging and several smaller adjacent north-plunging antiforms (fig. 1). The Igánánguit pink gneiss is distinctly foliated within about $100 \mathrm{~m}$ of amphibolite bands, but is almost undeformed farther away. There is no small-scale structural evidence that the large composite dome was formed by superimposed folding. It was probably produced by diapiric uprise of several small contemporaneous granodioritic to granitic plutons into the isoclinally folded amphibolite-gneiss country rocks.

Thin sections of the Igánánguit pink gneiss show that it ranges from granodioritic, relatively biotite-rich compositions $\left(\mathrm{An}_{20-27}\right.$ in plagioclase) to predominantly leucocratic, $\mathrm{K}$-feldspar rich rocks $\left(\mathrm{An}_{17-20}\right.$, optical determinations). The rocks mostly have granitic equilibrium textures between biotite, quartz, plagioclase and microcline. There is only minor muscovite/ sericite replacement in plagioclase feldspars and secondary growth of epidote.

The Qugssuk granite has invaded the area north of Qugssuk. It forms continuous exposures along the head of Qugssuk (S. Bak Jensen, personal communication, 1982), where mapping is not completed, and forms a small north-south elongated dome-like structure $c$. $10 \mathrm{~km}$ from the coast. Subconcordant, subvertical sheets extend several $\mathrm{km}$ further northwards. The Qugssuk granite very commonly forms agmatites with the country rock so that exact boundaries cannot be defined. The granite is a biotite-bearing, leucocratic, white to pale pinkish rock, rich in K-feldspar, and it very often grades into coarse-grained pegmatitic varieties. It generally has fresh granitic equilibrium textures and normally contains two feldspars (microcline and oligoclase $A n_{15-18}$ ), but occasionally microperthitic alkali feldspar and plagioclase. It forms intrusive subconcordant sheets in the streaky grey tonalitic gneisses to its west, whereas its relations to tonalitic and granodioritic rocks that belong to the Taser- 


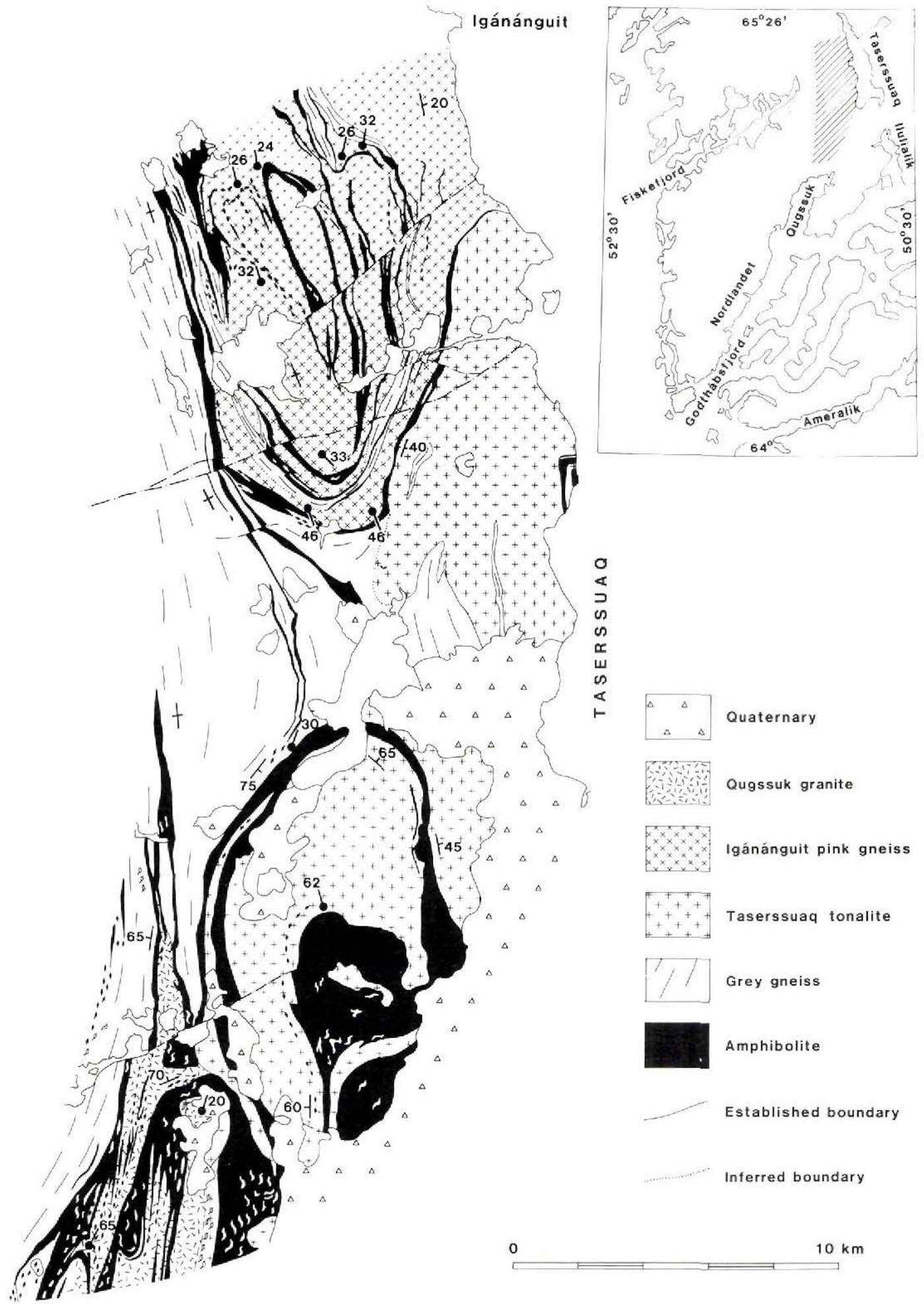

Fig. 1. Simplified geological map of the area west and south-west of Taserssuaq, north of Godthåbsfjord, with an index map of the Godthăbsfjord region. 
ssuaq tonalite towards the east suggest that it is derived from the latter by partial melting (Garde, 1984). The Qugssuk granite is locally foliated, e.g. along the eastern flank of the domal structure described above and at some coastal exposures at the head of Qugssuk.

Whereas the Igánánguit pink gneiss is generally separated from the grey gneiss by a screen of amphibolite, there are outcrops where Qugssuk granite is in contact with grey, probably retrogressed gneiss. The conclusion that the Qugssuk granite was emplaced during or after the retrogression and after the granulite facies episode is supported by a visual comparison with granulite facies granitic sheets of similar composition some $20 \mathrm{~km}$ further west (no chemical data are yet available from the latter). These latter sheets are also discordant with respect to gneisses of intermediate (tonalitic and dioritic) composition, some of which still have granulite facies parageneses. In contrast to the Qugssuk granite, the granulite facies granite sheets form featureless outcrops of pale or purplish coloured, rather fine-grained, granoblastic mesoperthite-bearing lithologies.

A puzzling locality was found in 1984 by one of us (A. P. N.) and V. R. McGregor at the head of Qugssuk a few kilometres south of the mapped area. Orthopyroxene and garnet occur in a granitic rock which forms agmatites with amphibolite, in what appear to be relict patches of granulite facies. If this granite could be shown to be part of the Qugssuk granite, it would seem that the granulite facies metamorphism here outlasted the intrusion of Qugssuk granite. This is not the case elsewhere. Alternatively the orthopyroxene and garnetbearing patches might represent restite material, derived from granulite facies rocks and retained in the magma when the anatectic Qugssuk granite melt was formed.

To summarise, field relations in the area where mapping has so far been completed indicate that the emplacement of the Qugssuk granite took place after granulite facies metamorphism, and also after the major episode of isoclinal folding. Both the Igánánguit pink gneiss and the Qugssuk granite appear to predate the straight belt deformation that affected the Godthåbsfjord region between 2700 and 2600 Ma ago (McGregor et al., 1983). Petrographic evidence indicates that neither the Igánánguit pink gneiss nor the Qugssuk granite suffered much from the retrogression that affected both the grey gneiss and the Taserssuaq tonalite. It is possible that the influx of the aqueous fluid necessary to bring about the retrogression also caused the partial melting that led to the formation of the Igánánguit pink gneiss and Qugssuk granite.

\section{Geochemistry}

A plot of available analysed samples in a $\mathrm{Na}_{2} \mathrm{O}-\mathrm{K}_{2} \mathrm{O}-\mathrm{CaO}$ triangle (fig. 2) shows that the Igánánguit pink gneiss forms a trend from the grey gneiss towards the $\mathrm{K}$ corner, and that the Qugssuk granite plots further towards this corner, with $\mathrm{K}_{2} \mathrm{O} / \mathrm{Na}_{2} \mathrm{O}$ ratios greater than one. Two analyses of Taserssuaq tonalite published by Hall (1984) are comparable to the more Ca-rich samples of the grey gneisses.

Trace elements have been plotted against $\mathrm{MgO}$ (fig. 3) in order to relate their concentrations to an index of crystal-liquid fractionation processes. $\mathrm{MgO}$ is preferred to $\mathrm{SiO}_{2}$ and alkalies because these latter elements are considered more mobile during high-grade metamorphic processes. $\mathrm{Rb}, \mathrm{Th}$ and $\mathrm{Pb}$ are enriched in the Igánánguit pink gneiss and even more so in the Qugssuk granite compared to the grey gneisses. In three granulite facies specimens of grey gneiss the same elements occur only in concentrations close to or below their detection limits, which strongly suggests that much of the $\mathrm{Rb}$, Th and $\mathrm{Pb}$ present in the grey 
Fig. 2. $\mathrm{Na}_{2} \mathrm{O}-\mathrm{K}_{2} \mathrm{O}-\mathrm{CaO}$ triangular plot for samples of grey gneiss, Taserssuaq tonalite, Igánánguit pink gneiss and Qugssuk granite.

\author{
Q
}
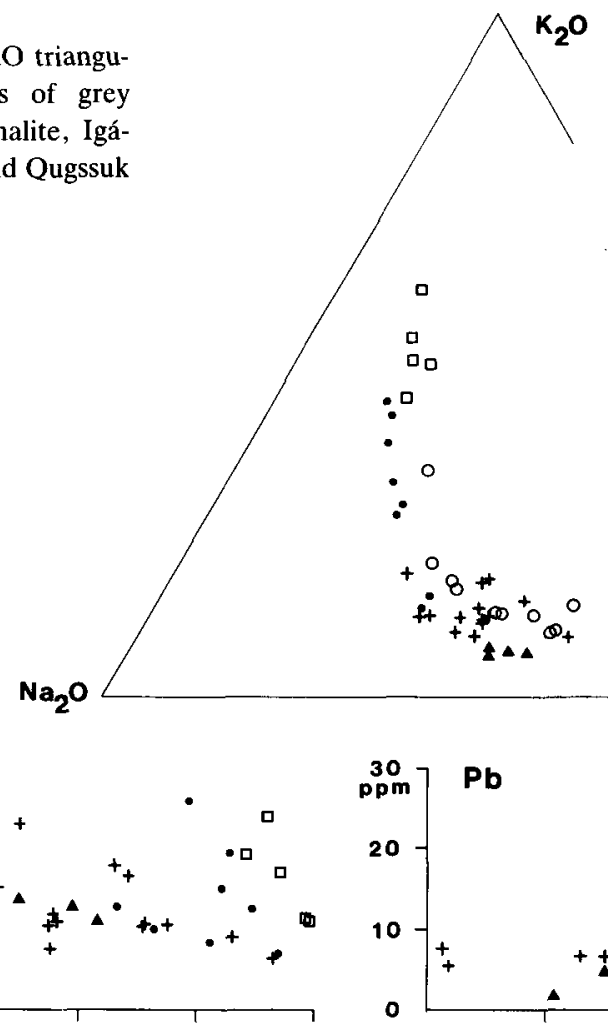

$\square$

$\square$
$\square$

$\because$
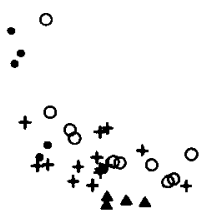

Qugssuk granite

- Igánánguit pink gneiss

- Taserssuaq tonalite

+ Grey gneiss

4 Grey gneiss (granulite facies)
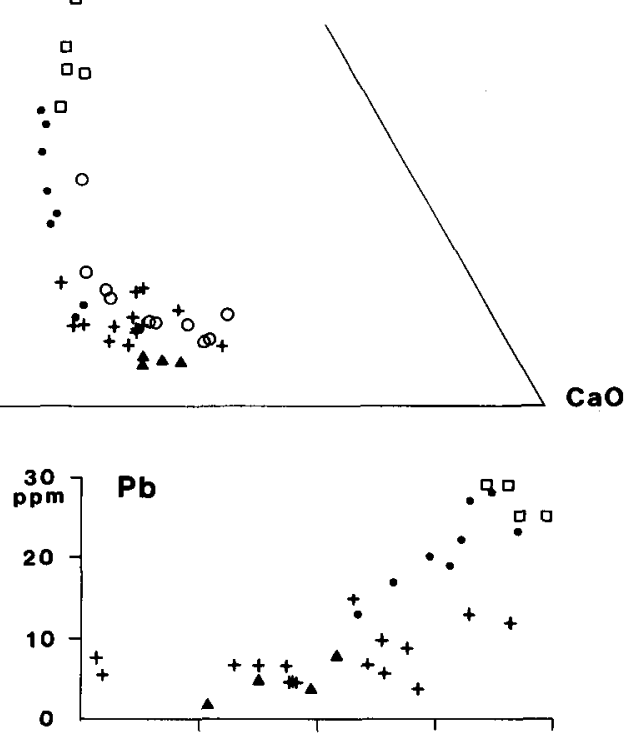
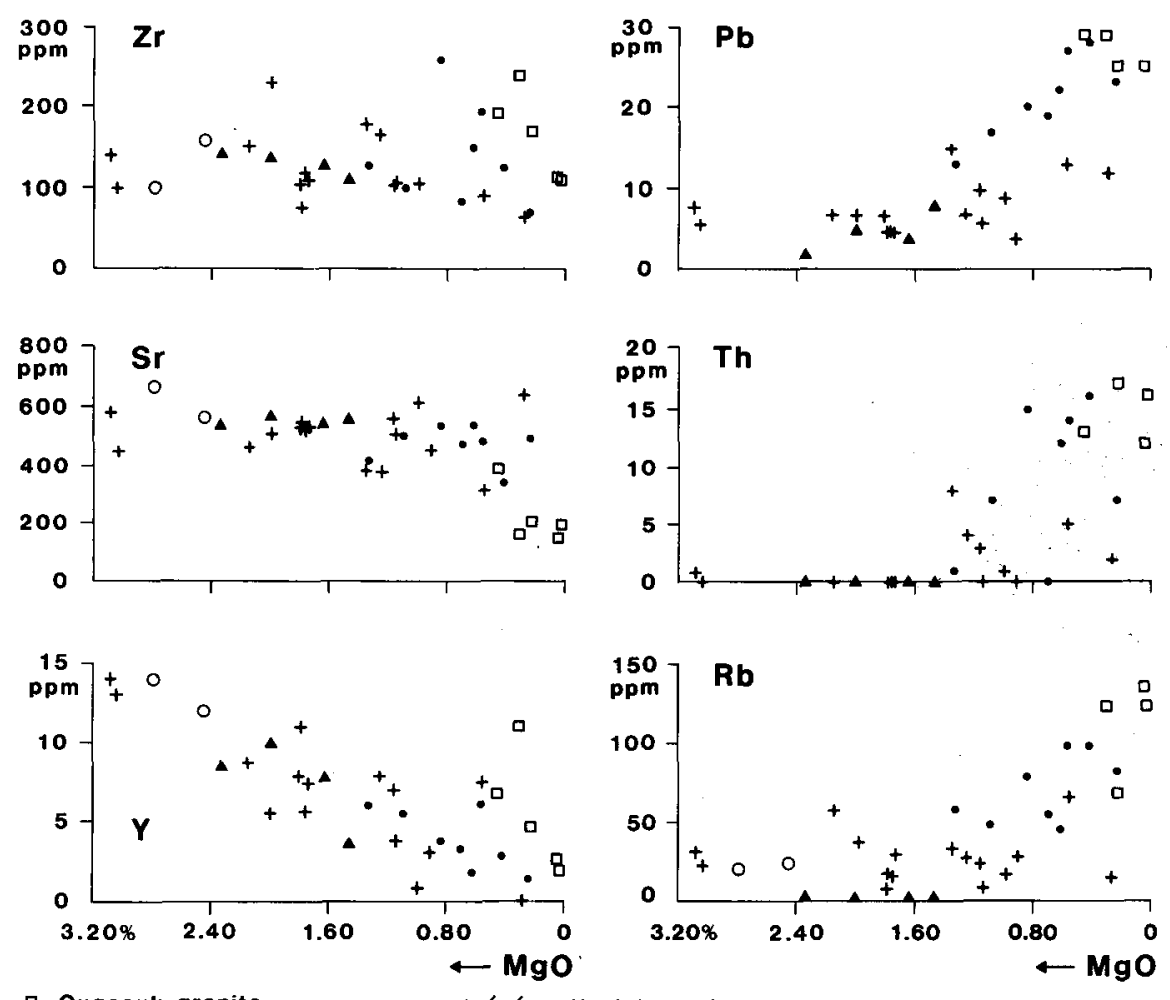

Qugssuk granite

- Igánánguit pink gneiss

+ Grey gneiss

- Taserssuaq tonalite

- Grey gneiss (granulite facies)

Fig. 3. Plots of $\mathrm{Zr}, \mathrm{Sr}, \mathrm{Y}, \mathrm{Pb}, \mathrm{Th}$, and $\mathrm{Rb}$ against $\mathrm{MgO}$ for grey gneiss, Taserssuaq tonalite, Igánánguit pink gneiss and Qugssuk granite. Data for Taserssuaq tonalites from Hall (1984). 
gneisses was introduced (or reintroduced) during retrogression. The patterns of $\mathrm{Sr}, \mathrm{Zr}$ and $\mathrm{Y}$ in all rocks resemble those found in cogenetic suites of igneous rocks, and suggest that these elements have not been very mobile during metamorphism.

The limited geochemical data presented above suffice to indicate that the Igánánguit pink gneiss and the Qugssuk granite are suites of progressively more evolved granitic rocks. With support from the field relations, the data suggest that they were derived by partial melting of crustal source rocks similar to the grey gneiss and Taserssuaq tonalite, not far below the present level of exposure. There is ample experimental, theoretical and field evidence for this process in the literature (see e.g. Green, 1977).

\section{Zircon U-Pb age determination of the Taserssuaq tonalite}

A zircon U-Pb age of $2982 \mathrm{Ma}$ was obtained from a sample of mafic tonalite (GGU 289171) collected near the eastern shore of Taserssuaq close to $65^{\circ} \mathrm{N}$. Five points from four different size fractions define a line close to the concordia with an upper intersection age of $2982 \pm 7$ Ma (R. T. Pidgeon, personal communication, 1984). The zircons consist of a very homogeneous suite of stubby, angular prisms with slightly blunted pyramids, with a uniform uranium content between 140-200 ppm (R. T. Pidgeon, personal communication).

\section{$\mathbf{R b}-\mathrm{Sr}$ isotopic results}

$\mathrm{Rb}$-Sr whole-rock data for rocks of the Taserssuaq tonalite, the Igánánguit pink gneiss and the Qugssuk granite are plotted in figs 4a-c and tabulated in Table 1.

The Taserssuaq tonalite is represented by 13 samples of mafic tonalitic rocks from the central and north-western parts of the outcrop and five samples of granodioritic composition from a restricted area south-west of Taserssuaq. The mafic tonalites have ${ }^{87} \mathrm{Rb} /{ }^{86} \mathrm{Sr}$ ratios of c. $0.1-0.4$, while the granodioritic rocks yield ${ }^{87} \mathrm{Rb} /{ }^{86} \mathrm{Sr}$ ratios in the range 1.2-1.6. A linear regression based on all 18 samples (fig. 4a) suggests a common age of $2882 \pm 36 \mathrm{Ma}$ ( $2 \sigma$ error) with an initial ratio of $0.7017 \pm 0.0002$. The 'mean squares of weighted deviates' (MSWD) of this estimate is about 1.6. This means that the scatter of the data points about the regression line could be caused by experimental error only, in which case the regression line would be an isochron.

The sample previously used for separation of the dated zircon, GGU 289171, was selected for further isotopic studies of separated mineral components. A $\mathrm{Rb}-\mathrm{Sr}$ isochron diagram (fig. 4d) shows that the minerals apatite, plagioclase and sphene equilibrated isotopically with other Sr-bearing minerals in the rock at about $2500 \mathrm{Ma}$. Biotite apparently lost radiogenic strontium again in Proterozoic time: approximately $1700 \mathrm{Ma}$ ago.

Twelve samples of Igánánguit pink gneiss were collected within an area of $c .20 \mathrm{~km}^{2}$. Plotted in the $\mathrm{Rb}-\mathrm{Sr}$ isochron diagram the isotopic data display a considerable scatter (fig. 4b). A regression on all samples has yielded a reference line of $2935 \pm 240 \mathrm{Ma}$ (initial ratio: 0.7021 \pm 0.004, MSWD $=9.6$ ). Six of the 12 samples, all collected within a central area of $1 \mathrm{~km}^{2}$, form a linear trend corresponding to an age of $3013 \pm 190 \mathrm{Ma}$ (initial ratio: $0.7013 \pm 0.0008$, MSWD $=1.98$ ).

The 13 samples of Qugssuk granite define an isochron of $2969 \pm 32 \mathrm{Ma}$ with an initial ratio of $0.7020 \pm 0.0003$. The MSWD value is 1.09 and suggests that an isochron has been obtained on these rocks. 
Table 1. Rb-Sr whole-rock data for Taserssuaq tonalite, Igánánguit pink gneiss and Qugssuk granite, and mineral Rb-Sr data for Taserssuaq tonalite (289171)

\begin{tabular}{|c|c|c|c|c|}
\hline & Rb ppm & Sr ppm & ${ }^{87} \mathrm{Rb} /{ }^{86} \mathrm{Sr}$ & ${ }^{87} \mathrm{Sr}{ }^{86} \mathrm{Sr}$ \\
\hline \multicolumn{5}{|c|}{ Taserssuaq tonalite (asterisks indicate granodioritic samples) } \\
\hline $\begin{array}{l}182134 \\
182159 \\
182160 \\
277441 \\
277445 \\
288610 \\
288612 \\
288616 \\
288660 \\
288662 \\
289040 \\
289099^{*} \\
289100^{*} \\
289101^{*} \\
289102^{*} \\
289103^{*} \\
290544 \\
290549\end{array}$ & $\begin{array}{r}55 \\
40 \\
25 \\
20 \\
45 \\
30 \\
30 \\
60 \\
40 \\
35 \\
55 \\
85 \\
85 \\
95 \\
115 \\
80 \\
25 \\
30\end{array}$ & $\begin{array}{l}605 \\
690 \\
655 \\
595 \\
465 \\
975 \\
660 \\
420 \\
615 \\
395 \\
390 \\
195 \\
220 \\
180 \\
240 \\
190 \\
610 \\
545\end{array}$ & $\begin{array}{l}0.268 \\
0.158 \\
0.112 \\
0.097 \\
0.267 \\
0.092 \\
0.139 \\
0.411 \\
0.189 \\
0.252 \\
0.395 \\
1.234 \\
1.135 \\
1.574 \\
1.378 \\
1.246 \\
0.119 \\
0.158\end{array}$ & $\begin{array}{l}0.7127 \\
0.7080 \\
0.7063 \\
0.7060 \\
0.7128 \\
0.7060 \\
0.7077 \\
0.7188 \\
0.7097 \\
0.7126 \\
0.7178 \\
0.7533 \\
0.7493 \\
0.7685 \\
0.7591 \\
0.7539 \\
0.7063 \\
0.7081\end{array}$ \\
\hline \multicolumn{5}{|l|}{ Igánánguit pink gneiss } \\
\hline $\begin{array}{l}278877 \\
278880 \\
278881 \\
278883 \\
278885 \\
278886 \\
278887 \\
278888 \\
278889 \\
278890 \\
278897 \\
289036\end{array}$ & $\begin{array}{r}80 \\
50 \\
60 \\
60 \\
110 \\
100 \\
76 \\
95 \\
55 \\
85 \\
60 \\
115\end{array}$ & $\begin{array}{l}500 \\
550 \\
630 \\
540 \\
550 \\
515 \\
485 \\
535 \\
610 \\
600 \\
440 \\
395\end{array}$ & $\begin{array}{l}0.475 \\
0.265 \\
0.267 \\
0.321 \\
0.584 \\
0.569 \\
0.446 \\
0.510 \\
0.252 \\
0.424 \\
0.398 \\
0.837\end{array}$ & $\begin{array}{l}0.7223 \\
0.7124 \\
0.7137 \\
0.7168 \\
0.7271 \\
0.7265 \\
0.7208 \\
0.7232 \\
0.7125 \\
0.7193 \\
0.7207 \\
0.7371\end{array}$ \\
\hline \multicolumn{5}{|l|}{ Qugssuk granite } \\
\hline $\begin{array}{l}182087 \\
278786 \\
289169-70 \\
289175 \\
289177 \\
289178 \\
289186 \\
289187 \\
289190 \\
289194 \\
289196 \\
289207 \\
289215\end{array}$ & $\begin{array}{r}55 \\
155 \\
110 \\
75 \\
105 \\
90 \\
195 \\
125 \\
140 \\
95 \\
110 \\
120 \\
95\end{array}$ & $\begin{array}{l}765 \\
170 \\
130 \\
565 \\
270 \\
250 \\
195 \\
350 \\
245 \\
760 \\
360 \\
250 \\
680\end{array}$ & $\begin{array}{l}0.199 \\
2.682 \\
2.469 \\
0.375 \\
1.049 \\
1.046 \\
2.877 \\
1.042 \\
1.640 \\
0.362 \\
0.878 \\
1.390 \\
0.398\end{array}$ & $\begin{array}{l}0.7103 \\
0.8178 \\
0.8085 \\
0.7180 \\
0.7475 \\
0.7476 \\
0.8244 \\
0.7465 \\
0.7717 \\
0.7178 \\
0.7395 \\
0.7629 \\
0.7194\end{array}$ \\
\hline \multicolumn{5}{|c|}{ Taserssuaq tonalite, mineral data } \\
\hline $\begin{array}{l}289171 \text { Apatite } \\
289171 \text { Biotite } \\
289171 \text { Epidote } \\
289171 \text { Plagioclase } \\
289171 \text { Sphene } \\
289171 \text { Whole-rock }\end{array}$ & $\begin{array}{c}0.23 \\
298 \\
6.21 \\
1.11 \\
0.82 \\
45\end{array}$ & $\begin{array}{c}238.5 \\
29.92 \\
2200 \\
300.7 \\
28.53 \\
450\end{array}$ & $\begin{array}{c}0.003 \\
30.96 \\
0.008 \\
0.011 \\
0.084 \\
0.287\end{array}$ & $\begin{array}{l}0.7051 \\
1.4652 \\
0.7137 \\
0.7057 \\
0.7080 \\
0.7155\end{array}$ \\
\hline
\end{tabular}

Sr-isotopic results were measured on a Varian MAT TH5 mass spectrometer equipped with a digital voltmeter and computerised data reduction and normalised to ${ }^{87} \mathrm{Sr} /{ }^{86} \mathrm{Sr}=0.70800$ for the Eimer and Amend standard. Reproducibility is $0.0002(1 \mathrm{o})$ on separate sample preparations. The precision of $\mathrm{Rb} / \mathrm{Sr}$ measurements by $\mathrm{X}$-ray fluorescence is within \pm c. $1 \%$ ( 2 o), and measurements on USGS standards G-2, GSP-1, AGV-1 and NBS-70a agree within $1 \%$ with the isotope dilution results of Pankjurst \& O'Nions (1973). The linear regression algorithm suggested by Williamson (1968) and the decay constant $1.42 \times 10^{-11} \mathrm{y}^{-1}$ for ${ }^{87} \mathrm{Rb}-{ }^{87} \mathrm{Sr}$ were used. All age results are given at the $2 \mathrm{o}$ level. 


\section{Discussion}

We believe that the zircon data give the best estimate of the age of intrusion of the Taserssuaq tonalite $(2982 \pm 7 \mathrm{Ma})$. The Taserssuaq tonalite is broadly correlated with the type Nûk gneisses, the parents of which were probably intruded shortly before $3000 \mathrm{Ma}$ (Baadsgaard \& McGregor, 1981). The whole-rock Rb-Sr data obtained on Taserssuaq tonalites and granodioritic rocks from within the tonalitic mass suggest an age ( $2882 \pm 36 \mathrm{Ma}$ ) which is significantly younger than the age set by the zircon data. This age, furthermore, conflicts with the isochron age of $2969 \pm 32 \mathrm{Ma}$ obtained for the Qugssuk granite, the intrusion of which, on field evidence, is shown to post-date the formation of the main mass of Taserssuaq tonalites.

In the following discussion the tonalitic and granodioritic varieties of the Taserssuaq tonalite are treated separately, in spite of the fact that there is no field evidence to suggest that the two rock types are not coeval.

Neither the mafic tonalites alone nor the granodioritic varieties have sufficient variation in $\mathrm{Rb} / \mathrm{Sr}$ ratios to allow the determination of a precise age estimate $(2827 \pm 115 \mathrm{Ma}$ and $2995 \pm$ $270 \mathrm{Ma}$, respectively). The apparent age difference is not statistically significant, and there is strong field evidence that the two varieties are essentially coeval. On the other hand the isotope data provide precise constraints on the evolution of ${ }^{87} \mathrm{Sr} /{ }^{86} \mathrm{Sr}$ ratios in the Taserssuaq tonalite as a function of time. In fig. 5 this evolution is shown for the period between 2980 and $2700 \mathrm{Ma}$. Starting with a value between 0.7010 and 0.7020 , the $\mathrm{Sr}$ isotopic ratios in the tonalitic mass increase at a rate of less than 0.0005 per $100 \mathrm{Ma}$, because of the very low $\mathrm{Rb} / \mathrm{Sr}$ ratios.

The granodioritic rocks of the Taserssuaq area have much higher $\mathrm{Rb} / \mathrm{Sr}$ ratios and consequently display a Sr-isotopic evolution quite different from that of their more mafic associates. Calculated back in time to $2980 \mathrm{Ma}$ the ${ }^{87} \mathrm{Sr} /{ }^{86} \mathrm{Sr}$ ratios of the granodiorite samples span a range of values between 0.6996 and 0.7005 . We draw attention to the fact that these values are particularly sensitive to experimental error. The calculated ratios could be affected by errors of about $0.0010-0.0014$ if statistical or systematic errors of up to $2 \%$ were present in the XRF determination of $\mathrm{Rb} / \mathrm{Sr}$ ratios. However, such errors would probably also have affected the data for the Qugssuk granite where $\mathrm{Rb} / \mathrm{Sr}$ ratios span the range of values found in the Taserssuaq granodiorites. Two samples of Qugssuk granite (GGU 289186 and 289190) do in fact fall outside the fan of evolution lines displayed by the remaining samples and are not included in the fan shown in fig. 5. The remaining granite samples display a fairly narrow range of ${ }^{87} \mathrm{Sr} /{ }^{86} \mathrm{Sr}$ values at $2980 \mathrm{Ma}$. This range appears to overlap the tonalitic range rather than the range obtained from the granodiorites. The $\mathrm{Rb}-\mathrm{Sr}$ data therefore permit the Qugssuk granite to have formed by anatectic mobilisation of the Taserssuaq tonalites in the manner suggested by field evidence. The granodiorites of the Taserssuaq body, on the other hand, span a range of ${ }^{87} \mathrm{Sr} /{ }^{86} \mathrm{Sr}$ values at $2980 \mathrm{Ma}$ below those of both tonalite and granite. The apparent initial ${ }^{87} \mathrm{Sr}{ }^{86} \mathrm{Sr}$ ratios of the granodiorites are lower than even those of the Amitsoq gneisses that formed at least $700 \mathrm{Ma}$ earlier (initial ratio $0.7010 \pm 0.0005$, Moorbath et al., 1972). Such low initial Sr isotopic ratios are difficult to explain. The isotopic data are more easily interpreted by assuming that the granodiorites obtained their present $\mathrm{Rb} / \mathrm{Sr}$ ratios at least $100 \mathrm{Ma}$ after the emplacement of the main tonalitic mass. The general relative abundance of retrograde hydrous minerals in the Taserssuaq pluton is indicative of substantial fluid circulation. Available geochemical data from the neighbouring grey gneisses 

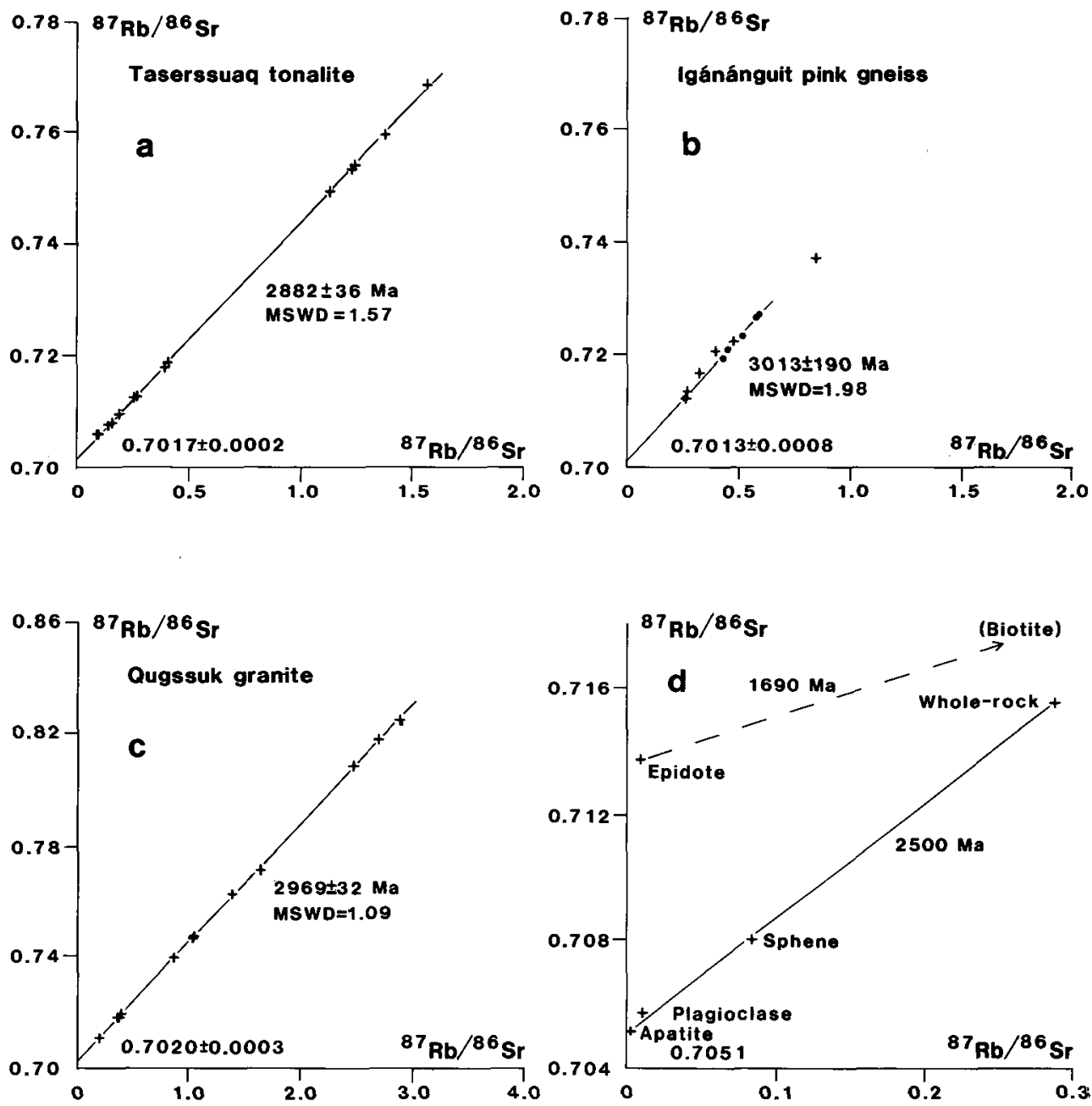

Fig. 4. Rb-Sr isochron diagrams. (a) Taserssuaq tonalite. (b) Igánánguit pink gneiss. Dots: samples from central area (see text) with their reference line. Crosses: other Igánánguit pink gneiss samples. (c) Qugssuk granite. (d) Isotopic data on minerals separated from mafic tonalite, sample GGU 289171.

suggest that $\mathrm{Rb}$ was especially mobile during retrogression. It is therefore likely that the $\mathrm{Rb}-\mathrm{Sr}$ data from the granodioritic rocks are best explained by a late $\mathrm{Rb}$ addition.

The Igánánguit pink gneisses also yield somewhat ambiguous data. The six central samples displaying a linear alignment in the Rb-Sr isochron diagram (fig. 4b) could have evolved from mafic tonalites with ${ }^{87} \mathrm{Sr} /{ }^{86} \mathrm{Sr}$ ratios near 0.7015 at $2980 \mathrm{Ma}$. The more scattered data points (in particular samples GGU 278883 and 278887) appear to have evolved from isotopically heterogeneous rocks with considerable enrichment in radiogenic strontium. Such rocks could not have formed directly from other rocks described in this paper until after 2900 Ma. 


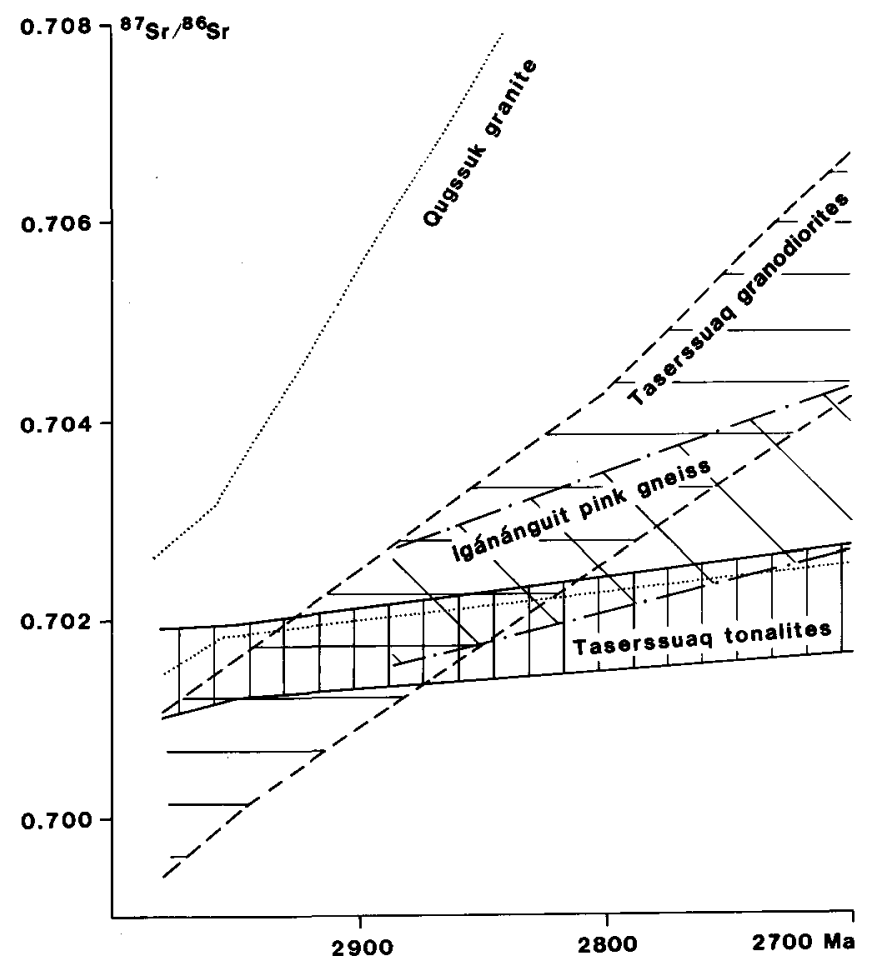

Fig. 5. Diagram showing the evolution of Sr isotopic compositions of whole-rock samples between 2980 and 2700 Ma.

The evidence from the Taserssuaq granodiorites and the odd samples from the Igánánguit pink gneiss force us to seriously consider the possibility of a fairly intense thermal event as well as trace element mobilisation, at some time after $2900 \mathrm{Ma}$.

The isotopic data on mineral separates from Taserssuaq tonalite sample GGU 289171 provide separate evidence for a late Archaean thermal event in the area strong enough to isotopically equilibrate the mineral systems of the rock. The age of $2500 \pm 140 \mathrm{Ma}$ based on apatite, plagioclase and sphene combined with whole-rock data agrees with age results reported by Moorbath et al. (1981) for the late Archaean Qôrqut granite complex (Brown et al., 1981): the intrusion was dated at $2530 \pm 30 \mathrm{Ma}$ using $\mathrm{Rb}$-Sr isotopes on whole-rock samples, and at $2580 \pm 80 \mathrm{Ma}$ by Pb-Pb work. Pankhurst et al. (1973) obtained an age of $2580 \pm 30$ Ma on pegmatite minerals: K-feldspar, muscovite and biotite from the same complex. The mineral data from the Taserssuaq tonalite suggest that the thermal activity recorded in the Qôrqut granite in the central parts of the Godthåbsfjord area also affected parts of the mainland north of Godthåbsfjord.

According to Pankhurst $e t$ al. all biotites investigated (except those from the Qôrqut granite pegmatite) yield $\mathrm{Rb}-\mathrm{Sr}$ ages between 1600 and $1700 \mathrm{Ma}$. This appears to be the case also in the Taserssuaq tonalite. Apparently biotite equilibrated with epidote only, without affecting the other mineral components. The slope of the line connecting epidote and biotite corresponds to an age of $1690 \mathrm{Ma}$. Mineral ages were also reported by Baadsgaard et al. (1976) from early Archaean Amîtsoq gneisses in outer Godthåbsfjord. The total of their 
complex data (from U-Th- $\mathrm{Pb}, \mathrm{Pb}-\mathrm{Pb}, \mathrm{Rb}-\mathrm{Sr}$ and $\mathrm{K}-\mathrm{Ar}$ systems) indicate three major metamorphic events close to 3600,2500 and $1550 \mathrm{Ma}$. A mid Proterozoic age was also obtained by Kalsbeek \& Taylor (1983, Pb-Pb and $\mathrm{Rb}-\mathrm{Sr}$ data) from a granite dyke at Isukasia northwest of lake Taserssuaq. This age seems to reflect a regional thermal event in the southern West Greenland craton, perhaps related to Nagssugtoqidian and Foxe-Rinkian metamorphism in central West Greenland (Pulvertaft, this volume).

\section{Conclusions}

The Taserssuaq tonalite, which is slightly younger than or coeval with the grey gneisses north of Godthåbsfjord, was probably intruded around $2980 \mathrm{Ma}$ ago, and both units are correlated with the tonalitic Nûk gneisses.

The late Archaean Rb-Sr whole-rock age of the Taserssuaq tonalite and $\mathrm{Rb}$-Sr ages of two groups of younger, more evolved granitic rocks, are mutually inconsistent and cannot with certainty be related to specific geological events. There are several possible reasons for this inconsistency. The ${ }^{87} \mathrm{Sr} /{ }^{86} \mathrm{Sr}$ isotopic evolution of the analysed rocks calculated back to 2980 $\mathrm{Ma}$, judged in the context of their field relations, leads to the suggestion of $\mathbf{R b}$ addition later than $2900 \mathrm{Ma}$ in part of the Taserssuaq pluton. In addition, geochemical data indicate $\mathbf{R b}$ mobility during retrograde metamorphism from granulite facies. The retrogression affected the Taserssuaq pluton, but apparently not the adjacent granitic rocks.

Mineral $\mathrm{Rb}-\mathrm{Sr}$ data from the Taserssuaq tonalite suggest thermal events at about 2500 and $1700 \mathrm{Ma}$.

If the isochron obtained for the Qugssuk granite dates an igneous event, and if late Archaean granulite facies metamorphism north of Godthåbsfjord was a regional synchronous event, it follows that retrogression from this event began at or before $2955 \mathrm{Ma}$, and that the late Archaean continental crust was mature enough for remobilisation of granitic melts by then.

The first published result of $\mathrm{Pb}-\mathrm{Pb}$ whole-rock dating from Nordlandet (Black et al., 1973, $\mathrm{Pb}$ extraction by volatilisation at high temperature) gave an age of $c .2850 \mathrm{Ma}$, which was interpreted as dating the granulite facies event. The more recent $\mathrm{Pb}-\mathrm{Pb}$ age of $3000 \pm 70 \mathrm{Ma}$ from Nordlandet and Sukkertoppen (Taylor et al., 1980, Pb obtained by electrodeposition) is in better agreement with the tentative conclusions presented here. However, granulite facies metamorphism in the Fiskenæsset area further south has been dated at $2800 \mathrm{Ma}$ (zircon U-Pb data, Pidgeon \& Kalsbeek, 1978).

Wells (1979) described prograde granulite facies metamorphism in the Buksefjorden area c. $100 \mathrm{~km}$ south of Qugssuk. He argued that the granulite facies metamorphism occurred near the bottom of a pile of tonalitic sheets that were injected by subhorizontal over-accretion. The thermal gradient developed by over-accretion would allow granulite facies parageneses to form during rising $\mathrm{P}$ and $\mathrm{T}$ conditions (and probably falling $P_{\mathrm{H}_{2} \mathrm{O}}$ ), and without extensive partial melting in the prograde phase. The geological development north of Godthåbsfjord may well have followed a similar course up to the point of granulite facies metamorphism. But the widespread retrogression (and intrusion of remobilised granitic s.l. material, perhaps related to this retrogression), which is significant north of Godthåbsfjord, is not parallelled in the Buksefjorden area according to Wells (1979). 
It has already been established that crustal reworking and injection of granitic material took place at intervals subsequent to $c .2800 \mathrm{Ma}$ in the Godthåbsfjord and Ivisartoq areas (e.g. McGregor et al., 1983; S. Robertson, personal communication, 1984), culminating with the Qôrqut granite complex at c. $2550 \mathrm{Ma}$. More work is needed to confirm our present conclusion that significant volumes of granitic (s.s.) mobilisates were formed to the north of Godthåbsfjord between 2900 and $3000 \mathrm{Ma}$ ago.

Acknowledgements. We would like to thank R. T. Pidgeon, Western Australian Institute of Technology, for providing the zircon analyses. J. C. Bailey and J. Christensen, Geological Institute, University of Copenhagen, are thanked for providing $\mathrm{X}$-ray analyses of trace elements, together with $\mathrm{P}$. Vindslev for mineral separates and P. Blom for able assistance in the isotope laboratory. F. Kalsbeek, GGU, P. N. Taylor, University of Oxford, D. Bridgwater and N. Springer, University of Copenhagen, and V. R. McGregor, Atammik, Greenland, are thanked for useful discussions and comments during preparation of the manuscript. The Danish National Science Research Council is thanked for funding the analytical facilities.

\section{References}

Allaart, J. H. (comp.) 1982: Geological map of Greenland 1:500 000, sheet 2. Copenhagen: Geol. Surv. Greenland.

Allaart, J. H., Jensen, S. B., McGregor, V. R. \& Walton, B. J. 1977: Reconnaissance mapping for the 1:500 000 map sheet in the Godthåb-Isua region, southern West Greenland. Rapp. Grønlands geol. Unders. 85, 50-54.

Baadsgaard, H. \& McGregor, V. R. 1981: The U-Th-Pb systematics of zircons from the type Nûk gneisses, Godthåbsfjord, West Greenland. Geochim. cosmochim. Acta 45, 1099-1109.

Baadsgaard, H., Lambert, R. St. J. \& Krupicka, J. 1976: Mineral isotopic age relationships in the polymetamorphic Amîtsoq gneisses, Godthåb district, West Greenland. Geochim. cosmochim. Acta 40, 513-527.

Black, L. P., Moorbath, S., Pankhurst, R. J. \& Windley, B. F. 1973: ${ }^{207} \mathrm{~Pb} /{ }^{206} \mathrm{~Pb}$ whole-rock age of the Archaean granulite facies metamorphic event in West Greenland. Nature 244, 50-53.

Bridgwater, D., Keto, L., McGregor, V. R. \& Myers, J. S. 1976: Archaean gneiss complex of West Greenland. In Escher, A. \& Watt, W. S. (edit.) Geology of Greenland, 18-75. Copenhagen: Geol. Surv. Greenland.

Brown, M., Friend, C. R. L., McGregor, V. R. \& Perkins, W. T. 1981: The late Archaean Qôrqut granite complex of southern West Greenland. J. Geophys. Res. 86, No. B11, 10617-10632.

Garde, A. A., Hall, R. P., Hughes, D. J., Jensen, S. B., Nutman, A. P. \& Stecher, O. 1983: Mapping of the Isukasia sheet, southern West Greenland. Rapp. Grønlands geol. Unders. 115, 20-29.

Garde, A. A. 1984: Field work between Fiskefjord and Godthåbsfjord, southern West Greenland. Rapp. Grønlands geol. Unders. 120, 45-50.

Green, D. H. (edit.) 1977: Experimental petrology related to extreme metamorphism. Tectonophysics 43, 1-167.

Hall, R. P. 1984: Comparative geochemistry of Archaean orthogneisses from the north-western quadrant of the Isukasia map sheet region, southern West Greenland. Rapp. Grønlands geol. Unders. 120, $37-45$.

Kalsbeek, F. \& Pidgeon, R. T. 1980: The geological significance of Rb-Sr whole-rock isochrons of polymetamorphic Archaean gneisses, Fiskenaesset area, southern West Greenland. Earth Planet. Sci. Lett. 50, 225-237.

Kalsbeek, F. \& Taylor, P. N. 1983: Anatectic origin of mid-Proterozoic granite dyke in the Isukasia area, West Greenland. $\mathrm{Pb}-\mathrm{Pb}$ and $\mathrm{Rb}-\mathrm{Sr}$ isotopic evidence. Rapp. Grønlands geol. Unders. 115, 38-42. 
McGregor, V. R., Bridgwater, D. \& Nutman, A. P. 1983: The Qârusuk dykes: post-Nûk, pre-Qôrqut granitoid magmatism in the Godthåb region, southern West Greenland. Rapp. Grønlands geol. Unders. 112, 101-112.

Moorbath, S., O'Nions, R. K., Pankhurst, R. J., Gale, N. H. \& McGregor, V. R. 1972: Further rubidium-strontium age determinations on the very early Precambrian rocks of the Godthåb district, West Greenland. Nature phys. Sci. 240, 78-82.

Moorbath, S., Taylor, P. N. \& Goodwin, R. 1981: Origin of granitic magma by crustal remobilization: $\mathrm{Rb}-\mathrm{Sr}$ and $\mathrm{Pb}-\mathrm{Pb}$ geochronology and isotope geochemistry of the late Archaean Qôrqut granite of southern West Greenland. Geochim. cosmochim. Acta 45, 1051-1060.

Pankhurst, R. J., Moorbath, S., Rex, D. E. \& Turner, G. 1973: Mineral age patterns in c. 3700 My old rocks from West Greenland. Earth Planet. Sci. Lett. 20, 157-170.

Pankhurst, R. J. \& O'Nions, R. K. 1973: Determination of Rb/Sr and ${ }^{87} \mathrm{Sr} /{ }^{86} \mathrm{Sr}$ ratios of some standard rocks and evaluation of X-ray fluorescence spectrometry in Rb-Sr geochemistry. Chem. Geol. 12, 127-136.

Pidgeon, R. T. \& Kalsbeek, F. 1978: Dating of igneous and metamorphic events in the Fiskenaesset region of southern West Greenland. Can. J. Earth Sci. 15, 2021-2025.

Taylor, P. N., Moorbath, S., Goodwin, R. \& Petrykowski, A. C. 1980: Crustal contamination as an indicator of the extent of early Archaean continental crust: $\mathrm{Pb}$ isotopic evidence from the late Archaean gneisses of West Greenland. Geochim. cosmochim. Acta 44, 1437-1453.

Wells, P. R. A. 1979: Chemical and thermal evolution of Archaean sialic crust, southern West Greenland. J. Petrology 20, 187-226.

Williamson, J. H. 1968: Least squares fitting of a straight line. Can. J. Physics 46, 1845-1847.

A. A. G.

Geological Survey of Greenland,

Øster Voldgade 10,

$D K-1350$ Copenhagen K,

Denmark.
O. L.,

Inst. of Petrology,

Univ. of Copenhagen,

Oster Voldgade 10,

$D K-1350$ Copenhagen $K$,

Denmark.
A. P. N., Dept of Earth Sciences, Memorial University of Newfoundland, St. John's, Newfoundland, Canada, A1B $3 X 5$. 